Paedagogia Christiana

2/28 (20I I) - ISSN 1505-6872

Roman E. Rogowski*

Wrocław

\title{
Teocentryzm czy antropocentryzm u podstaw chrześcijańskich postaw wobec przyrody
}

Duch Boży, który „unosił się nad wodami” (Rdz 1,2) i który działa ,jakby uderzenie gwałtownego wiatru" (Dz 2, 2), natchnął tajemniczego Autora Księgi Mądrości, by zapisał znamienne zdanie: „we wszystkim jest Twoje nieśmiertelne tchnienie, miłujesz bowiem wszystkie stworzenia" (Mdr 12, 1; 11, 24). Jakby echem tych słów jest wypowiedź Apostoła Pawła: „Duch przenika wszystko (panta)" (1 Kor 2, 10). A potem - dzięki Duchowi Świętemu - przyszła refleksja nad Bożym słowem i przybrała postać teologii, w ramach której Sergiusz Bułgakow napisał, że ,jedna i ta sama Sofia objawia się tak w Bogu, jaki i w stworzeniu"1, i zilustrował tę prawdę własnym doświadczeniem: „Góry Kaukazu... Przede mną płonął pierwszy dzień stworzenia. Wszystko było promienne, wszystko było pogodzone, przepełnione dźwięczącą radością. Serce było gotowe rozerwać się ze szczęścia. Nie ma życia i śmierci - jest tylko wieczność, nieruchome dzisiaj. «Teraz, o Panie, pozwalasz odejść!» - dźwięczało w duszy i przyrodzie... To On, dobry i miłujący Ojciec, Jego szata, Jego miłość ...”’. A literatura piękna, która może być siostrą teologii - „Pięknej damy Teologii”, jak to określił Nikołaj Gumilow, wyraża tę samą prawdę w języku literackim, gdy w powieści Nikosa

* Ks. prof. dr hab. Roman E. Rogowski, dyrektor Instytutu Teologii Systematycznej i kierownik I Katedry Teologii Dogmatycznej w Instytucie Teologii Systematycznej Papieskiego Wydziału Teologicznego we Wrocławiu.

${ }^{1}$ M. Łosski, Historia filozofii rosyjskiej, Kęty 2000, s. 255.

2 Tamże, s. 219. 
Kazntzakisa Grek Zorba czytamy: „Bóg co chwila przybiera inne oblicze i chwała temu, kto potrafi rozpoznać Go pod każdą z tych postaci”.

I właśnie to próbuje robić teologia, szukając odpowiedzi, czy u podstaw chrześcijańskich postaw wobec przyrody należy uwzględnić teocentryzm, czy antropocentryzm.

\section{Tajemnica stworzenia - „Wszystkie Pańskie dzieła: błogosławcie Pana..."}

Wprawdzie „teraz widzimy jakby w zwierciadle, niejasno” (1 Kor 13, 12), to jednak jeśli połączy się starotestamentalne Imię Boga: „Jestem, Który Jestem” (Wj 3, 14) z nowotestamentalnym określeniem: „Bóg jest miłością” (1 J 4, 8), to otrzymuje się najwspanialsze określenie Boga: „Jestem, Który Jestem Miłością". A do natury takiej Miłości należy otwierać się, dawać siebie, eksplodować miłością - i dlatego Bóg-Miłość stwarza świat, stwarza wszystko, co istnieje. I dlatego św. Paweł pisał: „Dla nas istnieje tylko jeden Bóg, Ojciec, od którego wszystko (panta) pochodzi i dla którego my istniejemy" (1 Kor 8, 6).

Szczególnym objawem Miłości było stworzenie człowieka, a objawem Mądrości było stworzenie go „na obraz Boży” (Rdz 1, 27) i powierzenie mu troski o całe stworzenie, by je uczynił ,sobie poddanym” (Rdz 1, 28). Stąd Autor Księgi Mądrości pisał: „W mądrości swojej stworzyłeś człowieka, by panował nad stworzeniami, co przez Ciebie się stały, by władał światem w świętości i sprawiedliwości, i w prawości serca sądy sprawował" (Mdr 9, 2-3). Psalmista dopowie: „Obdarzyłeś go władzą nad dziełami rąk Twoich, złożyłeś to wszystko pod jego stopy" (Ps 8, 7). Rzecz jednak w tym, że Bóg zobowiązuje człowieka, by w Jego imieniu władzę nad stworzeniem sprawował „w świętości i sprawiedliwości, i w prawości serca”! Żądanie Boga jest tym bardziej zrozumiałe, że człowiek przez swoje ciało jest cząstką tego stworzenia, bo Bóg ,ulepił człowieka z prochu ziemi” (Rdz 2, 7). A zatem człowiek, odnosząc się do całego stworzenia w ten sposób, uwielbia Tego, który je powołał do istnienia, a jednocześnie odnosi się z dobrocią do samego siebie.

Stworzony z miłości świat stanowi kreacyjną formę uwielbienia Boga „Jestem, Który Jestem Miłością”. Pięknie to wyrażają Psalmy: „Niebiosa niech głoszą chwałę Boga, / dzieło rąk jego nieboskłon obwieszcza" (Ps 19,2). „Niechaj cała ziemia Cię wielbi / i niechaj śpiewa Tobie, / niech imię Twoje śpiewa" (Ps 66, 4). Ale chyba najpiękniej i najbardziej wszechstronnie oddaje to uwielbienie „Pieśń trzech młodzieńców”, w której wymienione są prze- 
różne stworzenia i elementy natury, z obejmującym wszystko wezwaniem: „Wszystkie Pańskie dzieła, błogosławcie Pana!” (Dn 5, 57-82).

Wszystkie Pańskie dzieła, błogosławcie Pana, chwalcie i wywyższajcie Go na wieki! Aniołowie Pańscy, [...] Niebiosa, [...] Wszystkie wody pod niebem, [...] Wszystkie potęgi, [...] Słońce i księżycu, [...] Gwiazdy nieba, [...] Deszcze i rosy, [...] Wszystkie wichry niebieskie, [...] Ogniu i żarze, [...] Chłodzie i upale, [...] Rosy i szrony, [...] Mrozy i zima, [...] Lody i śniegi, [...] Dni i noce, $[\ldots]$ Światło i ciemności, [...] Błyskawice i chmury, [...] Niech ziemia błogosławi Pana, [...] Góry i pagórki, [...] Wszystkie rośliny ziemi, [...] źró$\mathrm{dła},[\ldots]$ Morza i rzeki, [...] Wieloryby i stworzenia morskie, [...] Wszelkie ptaki powietrzne, [...] Zwierzęta dzikie i trzody, [...] Synowie ludzcy, błogosławcie Pana, chwalcie i wywyższajcie Go na wieki!

Stanowi to podstawę do sformułowania wniosku, że w ramach Starego Przymierza można mówić o teocentryźmie jako typowej postawie człowieka wobec całego stworzenia. Jest rzeczą oczywistą, że w imię miłości Tego, który ,jest Miłością" (1 J 4, 8), ten teocentryzm jest przepełniony miłością Boga do człowieka, bo przecież „Bóg tak umiłował świat (kosmon), że Syna swego Jednorodzonego dał, aby każdy, kto w Niego wierzy, nie zginął, ale miał życie wieczne" (J 3, 16-17).

\section{Misterium Wcielenia - „Tak Bóg umilował świat...”}

Jeżeli literatura jest siostrą Teologii, to można ponownie skorzystać z jej wsparcia i zacytować pytanie Greka Zorby z powieści Kazantzakisa: „Szefie, czy ty wierzysz, że Bóg przybrał postać człowieka i narodził się w stajence, czy tylko sobie kpisz z nas?" Otóż to rzeczywiście prawda: Bóg stał się człowiekiem i w ten sposób cały wszechświat zyskał największe misterium, jakie stworzony świat może otrzymać z rąk Boga, który ,jest miłością" (1 J 4, 8). W tym misterium, zwanym przez teologów wschodnich z Włodzimierzem Sołowjowem na czele „Bogoczłowieczeństwem”, nastąpiło niezwykłe zjednoczenie Boga i człowieka, łaski i natury, a tym samym zjednoczenie teocentryzmu i antropocentryzmu jako podstaw w ujęciu całego stworzenia i całej przyrody. Inaczej mówiąc - od momentu Wcielenia, od chwili narodzenia „Bogoczłowieka”, nie można już dzielić podstaw chrześcijańskich postaw wobec przyrody na teocentryczne i antropocentryczne, bo w Bogu-Człowieku zostało pojednane ,wszystko z sobą: przez

3 Tamże, s. 135. 
Niego - i to, co na ziemi, i to, co w niebiosach" $(1 \mathrm{Kol} 1,20)$. Należałoby zatem mówić o chrystocentryzmie zarówno w tej problematyce, jak i we wszystkich innych.

Wcielony Syn Boży, Chrystus Jezus, jest „doświadczony we wszystkim na nasze podobieństwo" $(\mathrm{Hbr} 4,15)$ i jest dzieckiem naturalnego środowiska jak każdy człowiek. Urodzony w grocie, ochrzczony w rzece, kuszony na pustyni, często przebywał nad morzem, na górach i w miejscach pustynnych. Kochał szczególnie trzy typowe żywioły przyrody: górę (oros), pustynię (eremos) i wodę (hydor). Często w swoich naukach nawiązywał do przyrody: „przypatrzcie się liliom na polu” (Mt 6, 28), a „od drzewa figowego uczcie się przez podobieństwo" (Mt 24, 32), ,przypatrzcie się ptakom w powietrzu" (Mt 6, 26). W Jego przypowieściach występują nasienie i kąkol, gorczyca i krzew winny, sól i perła, a także owca. W porównaniach uciekał się do szumu wiatru i dobrych drzew, do owiec pośród wilków oraz węży i gołębi, do lisów, kur i kurcząt, a także do wyglądu nieba. Gdy konał na drzewie krzyża, była poruszona cała natura: „Ziemia zadrżała i skały zaczęły pękać, i mrok ogarnął całą ziemię" (Mt 27, 45-51).

Misterium chrystocentryzmu zostaje dopełnione przez Odkupienie i zstąpienie Chrystusa do Otchłani: „Zstąpił do niższych części ziemi” (Ef 4,9). To zstąpienie do serca wszechświata, by je odkupić i uświęcić, by w misterium Zmartwychwstania odnowić wszystko, co istnieje, jest wstępem do „nieba nowego i ziemi nowej” (Ap 21, 1).

I dlatego miał rację stary pasterz z bułgarskiego Pirynu, gdy mówił do nas, wędrujących po szczytach tych gór: „Szanuję przyrodę, bo przez to uwielbiam Boga, który ją stworzył, ale także okazuję dobroć dla ludzi, którzy w tej przyrodzie żyją. Przecież i ja żyję w tych górach, cieszę się słońcem i owcami! A Chrystus jest z nami ...”

\section{Liturgia kosmiczna - „On jest Pierworodnym wobec każdego stworzenia"}

„A Słowo stało się ciałem i rozbiło namiot wśród nas” - pisze św. Jan (J 1,14), ale przedtem ogłasza: „Na świecie było słowo, a świat (kosmos) stał się przez Nie" (J 1, 10). I dlatego ,wszystko jest stworzone i podtrzymywane w swoim istnieniu przez Niego i dla Niego" ${ }^{4}$. Potem wszystko zostało odkupione przez Niego i przebóstwione przez Jego zmartwychwstanie, i przeznaczone do stania się ,niebem nowym i ziemią nową” (Ap 21, 1). Stąd greccy

\footnotetext{
4 P. Rawling, The Cosmic Christ, London 1996, s. 65.
} 
Ojcowie Kościoła stworzyli chrystologię kosmiczną, której żywym centrum jest Chrystus Kosmiczny 5 .

Grek Zorba z powieści Kazantzakisa mawiał: „Gdybyśmy wiedzieli, o czym szepczą kamienie, kwiaty i deszcz! Może nas wołają, a my nie słyszymy. Kiedy otworzą się ludzkie uszy? Kiedy rozewrą się nasze oczy?" I rzeczywiście - gdyby otworzyły się nasze uszy i rozwarły nasze oczy, usłyszelibyśmy i zobaczyli Kosmiczną Liturgię na cześć Boga Stworzyciela i Syna Bożego, Kosmicznego Chrystusa: „Niech Ci służą wszelkie Twoje stworzenia” (Jdt 16, 14), ,za rydwan masz obłoki, przechadzasz się na skrzydłach wiatru" (Ps 104, 3).

W tej Kosmicznej Liturgii olbrzymią rolę odgrywa piękno, bo „stworzył je Twórca piękności” (Mdr 13, 3) i dlatego „,przed Nim kroczą majestat i piękno” (1 Krn 16, 27), a „wspaniałość gwiazd jest pięknością nieba, błyszczącą ozdobą na wysokościach Pana" (Syr 43, 9). Całe zatem stworzenie pozostaje na służbie Kosmicznej Liturgii. Pisze o tym Tertulian: „Modlą się wszyscy aniołowie i całe stworzenie, modlą się stada i dzikie zwierzęta zginając kolana. Wszystko, co wychodzi ze stajni i wypełza z nor nie podnosi bezużytecznie swoich paszcz ku niebu, lecz modli się, wydając dźwięki sobie właściwe. Nawet i ptaki, powstając ze snu, wznoszą się ku niebu i rozkładając na krzyż swoje skrzydła zamiast rąk mówią coś, co wydaje się być modlitwą".

Ta Kosmiczna Liturgia zmierza w ostateczności do tego, by - jak pisał Włodzimierz Sołowjow - ,zjednoczyć cały świat w jedno żywe ciało, w doskonały organizm Bogoczłowieczeństwa"'.

Tak więc teocentryzm i antropocentryzm realizują się w chrystocentryźmie kosmicznym. Odpowiada to integralnej zasadzie św. Pawła: „Dla mnie żyć - to Chrystus" (Fil 1, 21). A jeżeli tak, to chrześcijanin, włączając się w Liturgię Kosmiczną, jest zobowiązany do pewnych praktycznych postaw wobec przyrody i całego stworzenia. Najpierw winien dostrzegać wspaniałość i piękno całej natury, bo - jak pisał Paul Claudel w swoim „Dzienniku” - „Przyroda sławi swego Stwórcę nie tylko fiołkiem i jelonkiem, lecz również tygrysem i kaktusem". Następnie być na tyle otwartym, by doświadczać mistyki Pawłowej: „Od stworzenia świata niewidzialne Jego przymioty - wiekuista Jego potęga oraz Bóstwo - stają się widzialne dla umysłu przez Jego dzieła" (Rz 1, 20). Może dlatego Stary Gringo z powieści Carlosa Fuentesa wyznawał, że ,na pustyni dwa lub trzy razy dziennie można zobaczyć twarz Pana Boga". W końcu świat przyrody stanowi doskonałe miejsce odnowy, zarówno biologicznej, jak i duchowej, i dlatego Jezus powiada do

\footnotetext{
${ }^{5}$ G. Maloney, Chrystus Kosmiczny, Warszawa 1972, s. 92-170.

${ }^{6}$ M. Losski, dz. cyt., s. 155.
} 
swoich uczniów: „Pójdźcie wy sami na miejsce pustynne i wypocznijcie nieco" (Mk 6, 31).

W Apokalipsie czytamy: „Nie wyrządzajcie szkody ziemi ani morzu, ani drzewom!" (Ap 7, 3). Może to stanowić wezwanie, by szanować i nie niszczyć Bożego dzieła. W imię Liturgii Kosmicznej całej przyrodzie należy się wielki szacunek, troska o jej ochronę i mistyczne patrzenie na rolę, jaką spełnia w planach Bożych. W końcu całe stworzenie, cały wszechświat jest Kosmicznym Ciałem Chrystusa i nieustannie realizuje Kosmiczną Liturgię. Dawid z powieści C. Coccioli Pamiętniki króla Dawida wyznaje: „Nauczono mnie błogosławić Pana świata za rzeczy piękne i dobre, którymi raduje się człowiek, a które stanowią znak Jego obecności”.

\section{Theocentricism or Anthropocentrism as a Basis of Christian Attitudes toward Nature (Summary)}

If we search for theocentricism and anthropocentricism as a basis of Christian attitudes toward nature in creationist vision of God, the incarnational vision of God such division is not possible as in the mystery of Incarnation and Redemption God Man appears, who personifies both human and divine sides. The Incarnation results in the whole cosmos being the Body of the Cosmic Jesus Christ, in the Cosmic Liturgy being fulfilled, and the integral vision of nature has its basis in the cosmic christiology. 